\title{
The Method of Measuring Carbon Sinks Based on the Changes of oxygen concentration in Forest Canopy
}

CHANGSHAN XING ( $\square$ xcs5048@163.com)

Beijing Gongqing Forestry Farm

JIANG LV

Beijing Gongqing Forestry Farm

YUN SHI

Beijing Gongqing Forestry Farm

\section{Methods Article}

Keywords: Forest Carbon Sinks, Measurement, Average oxygen concentration, Carbon Sequestration, Carbon Sink

Posted Date: December 20th, 2021

DOI: https://doi.org/10.21203/rs.3.rs-1141066/v1

License: () (i) This work is licensed under a Creative Commons Attribution 4.0 International License. Read Full License 


\section{Abstract}

Measuring Forest Carbon Sinks is becoming a popular topic as the need of many countries' carbon neutrality plans. We demonstrate a simple and accurate method of Forest Carbon Sinks measurement. By observing the daily average oxygen concentration in the canopy, we found it presented a parabolic distribution from Spring to Fall in a year. The forest finished the cycle from releasing oxygen and sequestrating carbon dioxide to using oxygen and releasing carbon dioxide in this period. We calculated the carbon sequestration of the forest was $101.39 \mathrm{t} / \mathrm{hm}^{2} / \mathrm{y}$, the Carbon Sink was $15.09 \mathrm{t} / \mathrm{hm}{ }^{2} / \mathrm{y}$ by calculating the changes of oxygen concentration in a growth cycle, the Carbon Sink is $16.29 \%$ of the carbon sequestration.

\section{Introduction}

Measuring Forest Carbon Sinks is one of the most popular research by many countries' carbon neutrality plans. It is important to find an accurate way to calculate current Forest Carbon Sinks so that we can have an effective way to measure the function of the Forest Carbon Sinks. However, the most common way to measure the changes of carbon sequestration right now is to calculate the forest Gross Primary Productivity (GPP) not the forest net productivity [1]. The carbon flux method ${ }^{[2]}$ is based on monitoring the changes of carbon dioxide in the air, which is not only have large errors, but also cannot be verified by test and measurement.

\subsection{Overview of the research area}

The research area is called Beijing Gongqing Forestry Farm, which located in the northeast of Beijing, and the detail of the forestry are as follows:

1. The geographical coordinates are $166.40 \mathrm{E}$ and $40.10 \mathrm{~N}$;

2. The altitude is 25 meters;

3. The soil type is sandy soil;

4. The forest type is planted forest;

5. The main tree species are poplar;

6. The region has a warm temperate semi-humid continental monsoon climate with four distinct seasons, it is dry and windy in spring, hot and rainy in summer, cool and crisp in autumn and cold and dry in winter.

7. The annual average temperature is $11.5^{\circ} \mathrm{C}$,

8. The annual sunshine is about 2750 hours,

9. The average annual rainfall is about $625 \mathrm{~mm}$, it belongs to a relatively arid area.

\section{Materials And Methods}

\subsection{Experimental Setup}

\subsubsection{Forest Carbon Sinks}

A 30 meters high measuring tower was set in the center of the 160-hectare forest. The average tree height of poplar was 21 meters, the average canopy height was 12 meters, and the average tree age was 25 years. An oxygen concentration detector was installed at the 15 meters high of the measuring tower to ensure the detector is located in the middle of the canopy. Meanwhile, the error value of the oxygen concentration detector had been adjusted to less than $\pm 0.5 \%$. Continuously measured the oxygen concentration for one day and night every 5 minutes, and calculated the daily average oxygen concentration of the forest. The duration of the measurement was from January $1^{\text {st }}, 2020$, to December $31^{\text {st }}, 2020$.

\subsubsection{Corn Carbon Sequestration}

An oxygen concentration detector was installed at the center of a $10 * 25$ square meter cornfield. Through the growing up of the corn, the detector should also raise position to ensure the detector was always located at the middle-upper part of the cornstalk. Continuously measured the oxygen concentration for one day and night every 5 minutes, and calculated the daily average oxygen value of cornfield. The duration of the measurement was from May $1^{\text {st }}, 2020$, to July $14^{\text {th }}, 2020$, the sowing time of corn was May $1^{\text {st }}, 2020$, and the harvest time of corn was July $14^{\text {th }}, 2020$.

\section{Data Analysis}

\subsection{Forest Canopy oxygen concentration Data}

Since trees only begin to grow and release oxygen at a temperature higher than their biological zero, the biological zero of poplar is more than 10 degrees Celsius, and the average temperature of Gongqing Forestry Farm from March $10^{\text {th }}$ to March $24^{\text {th }}$ is 10.17 degrees Celsius, so the starting point of data recording in spring was March 10. The endpoint of data recording in autumn should be set at the time point which the oxygen concentration was higher than the starting point in spring, so the endpoint in autumn is October $5^{\text {th }}$. This research analyzes and processes the change of oxygen concentration in the whole day on April $14^{\text {th }}, 2020$ (Figure.1), the daily maximum temperature from March $10^{\text {th }}$ to October $5^{\text {th }}$ (Figure.2), and the daily average of oxygen concentration from March $10^{\text {th }}$ to October $5^{\text {th }}$ (Figure.3).

\section{Results And Analysis}


The daily variation of oxygen concentration value shows a wave model. On April $14^{\text {th }}, 2020$, the lowest oxygen concentration in a day and night is from $5: 30$ a.m. to 7:30 a.m., and the lowest oxygen concentration value is $20.39 \%$ Vol.; the highest oxygen concentration value in a day and night is from 1:00 p.m. to 3:00 p.m., and the highest oxygen concentration value is $21.23 \%$ Vol. So, the difference between the lowest and the highest oxygen concentration in April $14^{\text {th }}$ is about $4.12 \%$.

\subsection{The Relationship between Daily Average oxygen concentration and Daily Maximum Temperature}

According to Figure 2 and Figure 3, the average daily oxygen concentration in the canopy is basically consistent with the changing trend of daily maximum temperature, and the oxygen concentration increases or decreases with the rise and fall of temperature. The changing trend of oxygen concentration during a growth period showed the form of low in spring and autumn, high in summer.

\subsection{The Changes of Average oxygen concentration in time cell for 15 Consecutive Days}

By using the one-way ANOVA, the temperature difference of each 15-day time cell is significant. Therefore, the average value of oxygen concentration every 15 days is taken as a unit oxygen concentration value (Table 1). The first cell as the starting point is from March $10^{\text {th }}$ to $24^{\text {th }}$ in spring, the average oxygen concentration is $20.56 \% \mathrm{vol}$, and the average oxygen concentration gradually increases from spring to summer. The highest point appears in the seventh unit which is from June $8^{\text {th }}$ to $22^{\text {nd }}$ in summer, the average oxygen concentration is $20.99 \%$ vol, and the average oxygen concentration gradually decreases from summer to autumn. The last unit is the fourteenth unit, which is From September $21^{\text {st }}$ to October $5^{\text {th }}$ in autumn, and the average oxygen concentration is $20.63 \%$ Vol.

\subsection{The Measurement of Forest Carbon Sinks}

The formula of plant carbon sequestration is:

$$
M_{\mathrm{co} 2}=\left(\sum v\right) \rho h s\left(m r_{c o 2} / m r_{o 2}\right)
$$

$\mathbf{M}_{\mathrm{co2}}$ is the mass of plant fixed carbon dioxide, and $\sum v$ is the summation value of oxygen concentration, $\rho$ is the oxygen density $1.43 \mathrm{~kg} / \mathrm{m}^{3}, \mathbf{h}$ is the average height of the photosynthetic part of the plant, $\mathbf{s}$ is the area of the plant, $\mathrm{mr}_{\mathrm{co} 2}$ is the molecular weight of $\mathrm{CO}_{2} 44$, and $\mathrm{mr}_{\mathrm{o} 2}$ is the molecular weight of $\mathrm{O}_{2} 32$.

According to table 1, the carbon sequestration of forest in a growth cycle is $101458.5 \mathrm{~kg} / \mathrm{hm}^{2}$, equivalent to $101.46 \mathrm{t} / \mathrm{hm}^{2} \unrhd \mathrm{The}$ emission of carbon dioxide is $84942 \mathrm{~kg} / \mathrm{hm}^{2}$, Equivalent to $84.94 \mathrm{t} / \mathrm{hm}^{2}$; The Forest Carbon Sink is $16516.5 \mathrm{~kg}$, equivalent to $16.52 \mathrm{t} / \mathrm{hm}^{2}$, Forest Carbon Sink is $16.29 \%$ of carbon sequestration.

Table 1: Forest Carbon Sinks Meter 


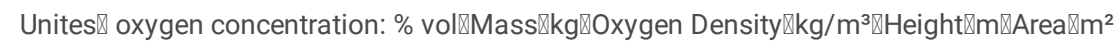

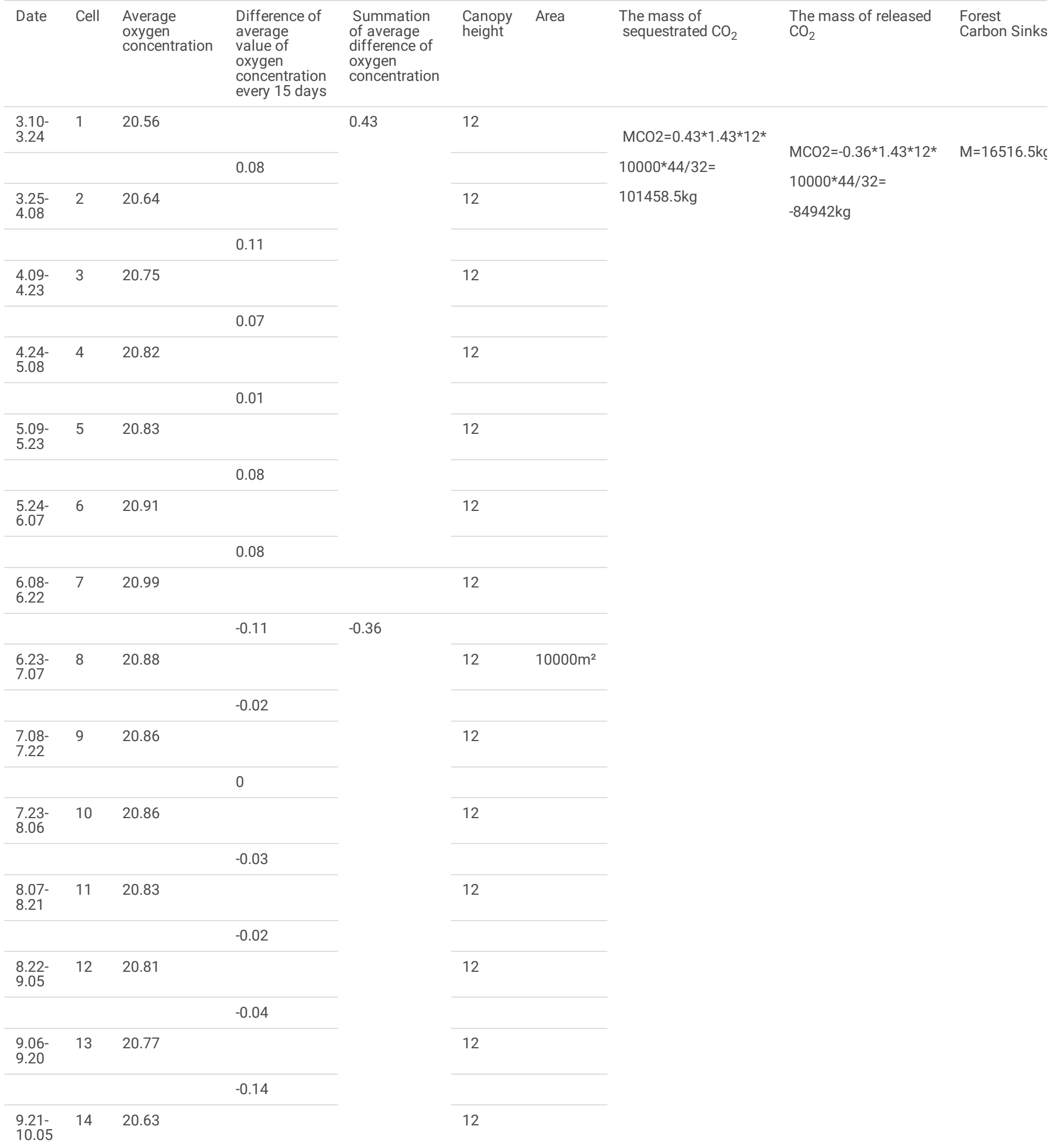

\subsection{The Measurement of Corn Carbon Sequestration}

The total carbon sequestration mass of corn during growth was $12.46 \mathrm{~kg}$, equivalent to $7.79 \mathrm{t} / \mathrm{hm}$. We harvested the corn at the observation point ( $\left.16 \mathrm{~m}^{2}\right)$ and obtained $23 \mathrm{~kg}$ dry matter include root, stem, leaf and corn. Based on the content of organic carbon in each part, we calculated the total mass of carbon sequestration was $9.95 \mathrm{~kg}$, and the measured carbon sequestration of corn accounted for $79.86 \%$ of the theoretically carbon sequestration. The measured 
carbon sequestration is lower than the theoretically carbon sequestration. It was because the fact that the carbon sequestration of roots and other plants in the soil cannot be fully collected.

Table 2₫Corn Carbon Sequestration Meter

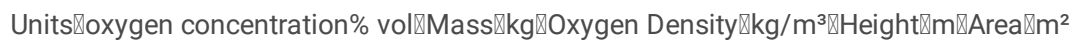

\begin{tabular}{|c|c|c|c|c|c|c|}
\hline Date & Cell & $\begin{array}{l}\text { Average oxygen } \\
\text { concentration }\end{array}$ & $\begin{array}{l}\text { Difference of average value of oxygen concentration } \\
\text { every } 15 \text { days }\end{array}$ & $\begin{array}{l}\text { The height of } \\
\text { cornstalk }\end{array}$ & Area & $\begin{array}{l}\text { The mass of } \\
\text { sequestrated } \mathrm{CO}_{2}\end{array}$ \\
\hline \multirow{2}{*}{$\begin{array}{l}5.1- \\
5.15\end{array}$} & 1 & 20.85 & & & 16 & \\
\hline & & & 0.03 & 0.6 & & 0.57 \\
\hline \multirow{2}{*}{$\begin{array}{l}5.16- \\
5.30\end{array}$} & 2 & 20.88 & & & & \\
\hline & & & 0.21 & 1.5 & & 9.91 \\
\hline \multirow{2}{*}{$\begin{array}{l}5.31- \\
6.14\end{array}$} & 3 & 21.09 & & & & \\
\hline & & & 0.03 & 2.1 & & 1.98 \\
\hline \multirow[t]{2}{*}{$\begin{array}{l}6.15- \\
6.29\end{array}$} & 4 & 21.12 & & & & \\
\hline & & & -0.09 & 2.2 & & \\
\hline $\begin{array}{l}6.30- \\
7.14\end{array}$ & 5 & 21.03 & & & & \\
\hline
\end{tabular}

\section{Conclusion And Discussion}

\subsection{Discussion}

\subsubsection{The Diurnal Variation of Forest Canopy oxygen concentration is Closely Related to Air Temperature}

The photosynthetic rate of trees in the growing season is closely related to the temperature. The lowest temperature in spring happened in 5:00 - 7:00. In this period, the trees had lowest photosynthetic rate of the day and the oxygen concentration in the air dropped to a minimum. The highest temperature happened in 13:00 $-15: 00$, in this period, the photosynthetic rate of trees reached to the strongest level of the day, and the oxygen concentration in the air also reached to the highest level.

\subsubsection{The Two Stages of Forest Growth Cycle: Carbon Sequestration and Carbon Release}

From spring to summer, the photosynthetic rate of trees increased with the increasing of temperature and the average oxygen concentration in the canopy increased gradually. It shows that during this period, the rate of photosynthesis of trees was higher than respiration rate. It was the stage of releasing oxygen and absorbing carbon dioxide. April $9^{\text {th }}$ to April $23^{\text {th }}$ was the fast-growing period of poplar branches and leaves, and it was also the period with the fastest increasing of oxygen concentration. From summer to autumn, the photosynthetic rate of trees decreased with the decreasing of temperature, and the average oxygen concentration in the canopy gradually decreased. This shows that during this period, the rate of photosynthesis of trees was lower than respiration. It was the stage of consuming oxygen and releasing carbon dioxide.

\subsubsection{The Fast-growing Period of Com is also the Peak of Carbon Sequestration}

According to the measurement results, the carbon sequestration from May $31^{\text {th }}$ to June $14^{\text {th }}$ was $9.91 \mathrm{~kg}$, accounting for $79.53 \%$ of the total measurement. Based on the observation data, this stage was the fastest period of high growth and sturdy growth of corn, and it was also the stage with the largest increasing of oxygen concentration. The results are in full agreement with the actual situation.

\subsection{Conclusion}

The measurement method shown in this paper can distinguish the total photosynthesis and total respiration of forest, which is very convenient to calculate the net productivity of forest. The validity and accuracy of the formula can be proved by the experiment of corn. Therefore, the method of carbon sequestration measurement based on the variation law of oxygen concentration in canopy is simple, accurate and real-time. It is applicable not only to forests, but also to crops, grasslands, wetlands and other scenes requiring carbon sequestration measurement.

\section{References}


1. Forestry Carbon Sequestration Editorial Board, 2016. Forestry Carbon Sequestration: practice in Beijing. China Forestry Publishing House. (In Chinese). 2. Li, N.Y., Lv, J., 2009. Carbon Inventory Methods. China Forestry Publishing House. (In Chinese).

\section{Figures}

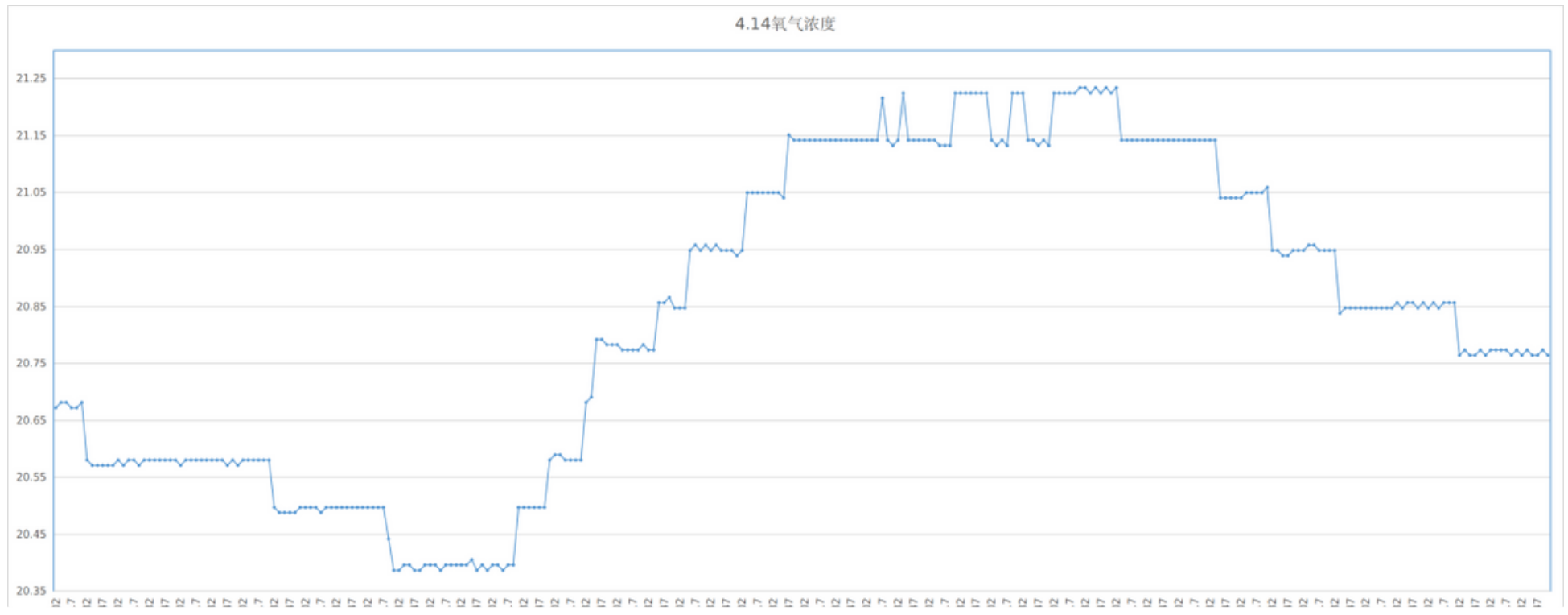

Figure 1

The change of oxygen concentration on April $14^{\text {th }}, 2020$

Figure 2

Daily maximum temperature curve from March $10^{\text {th }}$ to October $5^{\text {th }}$

Figure 3

Daily average oxygen concentration from March $10^{\text {th }}$ to October $5^{\text {th }}$ 